\title{
Human umbilical cord blood mononuclear cell transplantation for delayed encephalopathy after carbon monoxide intoxication
}

This article was published in the following Dove Press journal:

Journal of Neurorestoratology

19 August 2013

Number of times this article has been viewed

\author{
Dianrong Gong' \\ Haiyan $\mathrm{Yu}^{\prime}$ \\ Weihua Wang ${ }^{2}$ \\ Haixin Yang' \\ Fabin $\operatorname{Han}^{1,2}$ \\ 'Department of Neurology, ${ }^{2}$ Centre \\ for Stem Cells and Regenerative \\ Medicine, Liaocheng People's Hospital, \\ The Affiliated Liaocheng Hospital, \\ Taishan Medical University, Shandong, \\ People's Republic of China
}

\begin{abstract}
Stem cell transplantation is one of the potential treatments for neurological disorders. Since human umbilical cord stem cells have been shown to provide neuroprotection and promote neural regeneration, we have attempted to transplant the human umbilical cord blood mononuclear cells (hUCB-MNCs) to treat patients with delayed encephalopathy after carbon monoxide intoxication (DEACOI). The hUCB-MNCs were isolated from fresh umbilical cord blood and were given to patients subarachnoidally. Physical examinations, mini-mental state examination scores, and computed tomography scans were used to evaluate the improvement of symptoms, signs, and pathological changes of the patient's brain before and after hUCBMNC transplantation. A total of 12 patients with DEACOI were treated with hUCB-MNCs in this study. We found that most of the patients have shown significant improvements in movement, behavior, and cognitive function, and improved brain images in 1-4 months from the first transplantation of hUCB-MNCs. None of these patients have been observed to have any severe adverse effects. Our study suggests that the hUCB-MNC transplantation may be a safe and effective treatment for DEACOI. Further studies and clinical trials with more cases, using more systematic scoring methods, are needed to evaluate brain structural and functional improvements in patients with DEACOI after hUCB-MNC therapy.
\end{abstract}

Keywords: human umbilical cord blood mononuclear cells, transplantation, delayed encephalopathy after carbon monoxide intoxication, MMSE

\section{Introduction}

Carbon monoxide (CO) intoxication is one of the most severe lethal conditions for persons exposed to excess $\mathrm{CO}$ in industrial and living environments. Since the affinity of CO to hemoglobin is more than 250 times higher than that of oxygen, the formation of carboxyhemoglobin decreases the transport of blood oxygen to the tissues and causes reduced oxygen availability (hypoxia). ${ }^{1}$ The common symptoms of acute $\mathrm{CO}$ intoxication are headache, nausea, vomiting, transient loss of consciousness, altered mental status, and deep coma. Most patients with acute $\mathrm{CO}$ intoxication can recover from the first week of the acute phase; however, around $1 \%-30 \%$ of patients develop delayed encephalopathy after CO intoxication (DEACOI) 2-4 weeks after recovery from the acute $\mathrm{CO}$ poisoning. The main clinical characteristics of DEACOI include neurological, cognitive, and psychological symptoms and signs. Pathologically, patients with DEACOI have several regions of brain lesions, which include the cortex, cerebellum, and substantial nigra., ${ }^{2,3}$ Brain lesions also occur in the white matter and basal ganglia. Even though hyperbaric oxygen is a useful treatment for the acute phase of $\mathrm{CO}$ intoxication, there are no effective treatments for patients with DEACOI. 
One potential therapeutic approach is to use stem cells, through different transplantation methods, to repair and protect the damaged neurons and glial cells caused by DEACOI. ${ }^{4,5}$ Neural stem cells were proposed to be a useful cell-based therapy for neurological disease because of their ability to differentiate into functional neural cells; ${ }^{6-8}$ however, there are several issues such as the ethical concerns and immune rejection problems with the clinical application of the neural stem cells. The preclinical safety, efficacy, and ethical problems associated with neural stem cells need to be considered.

Human umbilical cord blood (hUCB) cells were reported to treat neurological disorders, as they have been shown to demonstrate neuroprotection, immunomodulation, and stimulation of neuroregeneration. ${ }^{9,10}$ Since hUCB cells are easily obtained and have the ability to differentiate into neurons, hUCB cell transplantation has been shown to be effective in animal models of neurodegenerative diseases such as Parkinson's disease, ${ }^{11,12}$ Alzheimer's disease, ${ }^{13}$ and amyotrophic lateral sclerosis. ${ }^{14,15} \mathrm{~A}$ recent study indicated that the hUCB-derived mesenchymal stem cells can reduce the apoptosis of cultured hippocampal neurons induced by amyloid- $\beta$ (A $\beta)$, the toxic protein of Alzheimer's disease. ${ }^{16}$ Furthermore, the hUCB mesenchymal stem cells were found to rescue learning and memory function in the Alzheimer's disease mouse model. ${ }^{17}$ Other studies have also shown that hUCB cell transplantation is a safe and effective therapeutic approach for spinal cord injury and stroke. ${ }^{18}$ We investigated the safety and efficacy of hUCB mononuclear cells (hUCBMNCs) transplantation to treat patients with DEACOI and evaluated the achieved beneficial effects.

\section{Materials and methods Patients}

Originally, 14 patients with DEACOI were enrolled in this study, which was approved by the ethical committee of Liaocheng People's Hospital, and each patient completed an informed consent form. The patients were diagnosed with DEACOI according to the criteria described in a previous publication. ${ }^{19}$ Each patient had accidentally been intoxicated by passively inhaling $\mathrm{CO}$ and then developed DEACOI 2-6 weeks after recovery from the acute phase. They had at least one of the following symptoms: cognitive and mental dysfunctions; extrapyramidal features such as the rigidity, dystonia, and resting tremor; other neurological signs including dysmetria and small step gait; urinary incontinence. All of the patients had been excluded for mental illness, dementia, and physical dysfunction.

\section{Isolation and preparation of hUCB stem cells}

The hUCB stem cells were collected immediately after the birth of newborns. All hUCB cell samples were collected in the same hospital (Liaocheng People's Hospital) and were collected from both males and females, as the distinction does not affect the quality of the mononuclear cells. A volume of 100-150 mL of umbilical cord blood was collected from each healthy donor, and the hUCB-MNCs were isolated using SCR-200I extraction kit (Zhonglianda Biological Inc., Yingchuan, Ningxia, People's Republic of China). It took approximately 3 hours from the time of umbilical cord blood collection to the mononuclear cell extraction, and it took less than 1 hour from the extraction to the time of transplantation. The transplantation procedure was carried out in a sterilized operating room. Approximately $1.0-2.0 \times 10^{8} \mathrm{hUCB}-\mathrm{MNCs}$ in a $3-4 \mathrm{~mL}$ suspension in phosphate buffered saline were injected by lumbar puncture into the patient's subarachnoid space over a period of 2-3 minutes.

\section{Physical examination and mini-mental state examination scoring}

To evaluate the therapeutic efficacy of the hUCB-MNC transplantation, physical examinations were performed on all patients by two neurologists, and the mini-mental state examination (MMSE) scores were used to evaluate the recovery of cognitive and mental dysfunctions. No patients had been observed to have any fever, headaches, back pain, or other adverse reactions in the first few days after treatment or thereafter during the follow-up study. We conducted 4-6 consecutive months of follow-up visits to study the safety and therapeutic efficacy of the hUCB-MNC transplantation in 12 patients (two were lost to follow-up).

\section{CT image analysis}

In order to understand the recovery of the brain lesions after hUCB-MNC transplantation therapy, we used a computed tomography (CT) scan to examine the brain structure changes in these patients. The images were then viewed by $\mathrm{CT}$ technologists and neurologists to identify the abnormal changes in the brain. Brain slices appear gray on a CT scan, and any abnormalities are shown as darker or lighter areas in the brain and around tissues.

\section{Laboratory tests}

Before transplantation, the blood, urine, stool, biochemical parameters, tumor markers, and possibility for the presence of 
virus and microorganism were examined for all 12 patients, and were examined for some of the patients after transplantation therapy.

\section{Statistical analysis}

SPSS statistical software (IBM Corporation, Armonk, NY, USA) was used to compare the cognitive improvement effects of hUCB-MNC transplantation among different treatment groups using analysis of variance (one-way ANOVA).

\section{Results}

In this study, we have investigated the safety and therapeutic effects of hUCB-MNC transplantation in patients with DEACOI. We treated 14 patients, but only 12 patients completed the 4-month follow-up visit. Their ages (mean \pm standard deviation) were in the range of 42-72 years $(59.7 \pm 11.2)$. All patients had a history of $\mathrm{CO}$ poisoning coma with a coma time of $2-20$ hours $(9.3 \pm 6.4)$ and a temporary asymptomatic period (pseudorecovery) of 6-30 days $(17.3 \pm 8.1)$ after the acute phase. All these patients received conventional hyperbaric oxygen therapy after acute $\mathrm{CO}$ intoxication onset, but the disease still progressed rapidly. The earliest symptom of patients with DEACOI is mental impairment. The other symptoms and signs of DEACOI include disturbance of consciousness, behavioral abnormalities, decorticate state, extrapyramidal symptoms, urinary incontinence, and increased muscle tension changes, which are summarized in Table 1.

To avoid the possible infections derived from the allogenic transplantation, the hUCB-MNCs were tested for quality control of the clinical applications after extraction from the hUCB. Each batch of cells was confirmed negative for endotoxin, hepatitis $\mathrm{B}$, and mycoplasma, and only the qualified hUBC-MNCs were allowed to be transplanted to patients. All the patients were followed-up for up to 6 months after transplantation. Since some patients could not be followed for a consecutive 6 months, we had only 12 patients who completed the 4 months of follow-up study. No adverse effects or immunological rejections were noted after transplantation during the 4 months of study, with some patients having been observed for more than 6 months with no adverse effects noted. Since the clinical characteristics between the patients varied, we created three scales to evaluate the improvement after transplantation of the hUCB-MNCs so that we could perform the statistical analysis in this study. These three scales are as follows: complete recovery, which indicates that the patient has recovered to the normal status as they were before the
CO intoxication; partial recovery, which indicates that the patient has recovered but still has some unconsciousness problems; and no response, which indicates that the patient did not have any observable improvements in clinical manifestations of DEACOI. We found that the effective rate of hUCB-MNC transplantation for DEACOI is $100 \%$. Seven of the 12 patients completely recovered and five of the 12 patients are partially recovered. The overall therapeutic effects of hUCB-MNC transplantation in these 12 DEACOI patients are shown in Table 2.

In order to evaluate the improvements in cognitive and mental dysfunctions after hUCB-NMC transplantation, the MMSE was used to record the changes of the neurological and cognitive impairments. We used the following scale to assess the recovery of cognitive and mental conditions: scores on the MMSE range from 0-30, with scores of 25 or higher being traditionally considered normal. Scores less than 10 generally indicate severe impairment, while scores between 10-19 indicate moderate dementia. ${ }^{20}$ We evaluated the MMSE scores of the patients; the average MMSE scores of the 12 patients before transplantation and 1, 2, and 4 months after transplantation were 1.86, 6.93, 16.5, and 23.14, respectively. Statistical analysis showed that the MMSE scores of the patients were significantly increased at 1,2 , and 4 months after transplantation compared to the MMSE scores of the patients before transplantation. Moreover the MMSE scores of patients were significantly increased at the time of 1,2 , and 4 months after transplantation compared to each other as shown in Figure 1 $(F=33.098, P<0.01)$.

To analyze the changes in the brains of the patients, we used CT scan imaging to record the changes of the brain lesions before transplantation, as well as 1, 2, and 4 months after hUCB-MNC transplantation. CT examination was performed on all 12 patients before the hUCB-MNC transplantation. Ten of the 12 patients had abnormal CT images, while two patients had normal brain CT images before transplantation. Abnormal changes as observed by CT scan included symmetric abnormally low signal intensities and diffused images in bilateral cerebral hemisphere subcortex, the limb of internal capsule, and basal ganglia in ten patients. As some patients declined to take the CT examination, only five patients were examined by $\mathrm{CT}$ after hUCB-MNC transplantation. As a result, 4 months after transplantation, the abnormal brain diffusion of the five patients had disappeared, as shown for one patient in Figure 2, suggesting the transplanted hUCB-MNC improved recovery of the injured brain regions in patients with DEACOI. 
Table I The clinical characteristics of the patients with DEACOI before and after the hUCB-MNC transplantation

\begin{tabular}{|c|c|c|c|c|c|c|c|}
\hline \multirow[t]{2}{*}{ Patient } & \multirow{2}{*}{$\begin{array}{l}\text { Age }(y) / \\
\operatorname{sex}\end{array}$} & \multirow{2}{*}{$\begin{array}{l}\text { Coma } \\
\text { time (h) }\end{array}$} & \multirow{2}{*}{$\begin{array}{l}\text { Pseudorecovery } \\
\text { time (d) }\end{array}$} & \multicolumn{4}{|l|}{ Neurological features } \\
\hline & & & & Before & I month after & 2 months after & 4 months after \\
\hline 1 & 72/female & 10 & 14 & $\begin{array}{l}\text { Unconsciousness, urine } \\
\text { incontinence, decorticated } \\
\text { state, extrapyramidal } \\
\text { abnormality }\end{array}$ & None & None & None \\
\hline 2 & 66/female & 5 & 6 & $\begin{array}{l}\text { Unconsciousness, urine } \\
\text { incontinence, decorticated } \\
\text { state, extrapyramidal } \\
\text { abnormality }\end{array}$ & Urine incontinence & None & None \\
\hline 3 & $57 /$ female & 9 & 26 & $\begin{array}{l}\text { Unconsciousness, urine } \\
\text { incontinence, decorticated } \\
\text { state, extrapyramidal } \\
\text { abnormality, pathologic } \\
\text { reflection }\end{array}$ & $\begin{array}{l}\text { Urine incontinence, } \\
\text { pathologic reflection }\end{array}$ & $\begin{array}{l}\text { Pathologic } \\
\text { reflection }\end{array}$ & None \\
\hline 4 & $71 / \mathrm{male}$ & 4 & 15 & Urine incontinence & Urine incontinence & None & None \\
\hline 5 & $61 / \mathrm{male}$ & 20 & 15 & $\begin{array}{l}\text { Unconsciousness, urine } \\
\text { incontinence, decorticated } \\
\text { state, extrapyramidal } \\
\text { abnormality, pathologic } \\
\text { reflection }\end{array}$ & $\begin{array}{l}\text { Urine incontinence, } \\
\text { pathologic reflection }\end{array}$ & $\begin{array}{l}\text { Pathologic } \\
\text { reflection }\end{array}$ & None \\
\hline 6 & $49 /$ male & 2 & 15 & $\begin{array}{l}\text { Urine incontinence, } \\
\text { psychological abnormality, } \\
\text { extrapyramidal abnormality }\end{array}$ & $\begin{array}{l}\text { Urine incontinence, } \\
\text { psychological } \\
\text { abnormality, } \\
\text { extrapyramidal } \\
\text { abnormality }\end{array}$ & None & None \\
\hline 7 & $42 /$ female & 15 & 30 & $\begin{array}{l}\text { Unconsciousness, urine } \\
\text { incontinence, decorticated } \\
\text { state, extrapyramidal } \\
\text { abnormality }\end{array}$ & None & None & None \\
\hline 8 & $70 /$ male & 10 & 18 & $\begin{array}{l}\text { Urine incontinence, } \\
\text { pathologic reflection, } \\
\text { extrapyramidal abnormality }\end{array}$ & $\begin{array}{l}\text { Urine incontinence, } \\
\text { pathologic reflection, } \\
\text { extrapyramidal } \\
\text { abnormality }\end{array}$ & $\begin{array}{l}\text { Pathologic } \\
\text { reflection }\end{array}$ & $\begin{array}{l}\text { Pathologic } \\
\text { reflection }\end{array}$ \\
\hline 9 & $43 /$ male & 10 & 4 & $\begin{array}{l}\text { Urine incontinence, } \\
\text { pathologic reflection, } \\
\text { extrapyramidal abnormality }\end{array}$ & $\begin{array}{l}\text { Urine incontinence, } \\
\text { pathologic reflection, } \\
\text { extrapyramidal } \\
\text { abnormality }\end{array}$ & $\begin{array}{l}\text { Pathologic } \\
\text { reflection, } \\
\text { extrapyramidal } \\
\text { abnormality }\end{array}$ & None \\
\hline 10 & $60 /$ female & 16 & 23 & $\begin{array}{l}\text { Unconsciousness, urine } \\
\text { incontinence, decorticated } \\
\text { state, extrapyramidal } \\
\text { abnormality, pathologic } \\
\text { reflection }\end{array}$ & $\begin{array}{l}\text { Urine incontinence, } \\
\text { pathologic reflection, } \\
\text { extrapyramidal } \\
\text { abnormality }\end{array}$ & $\begin{array}{l}\text { Urine } \\
\text { incontinence, } \\
\text { pathologic } \\
\text { reflection, } \\
\text { extrapyramidal } \\
\text { abnormality }\end{array}$ & $\begin{array}{l}\text { Pathologic } \\
\text { reflection, } \\
\text { extra- } \\
\text { Pyramidal } \\
\text { abnormality }\end{array}$ \\
\hline 11 & $49 /$ male & 20 & 19 & Psychological abnormality & $\begin{array}{l}\text { Psychological } \\
\text { abnormality }\end{array}$ & $\begin{array}{l}\text { Psychological } \\
\text { abnormality }\end{array}$ & None \\
\hline 12 & $46 /$ male & 10 & 45 & $\begin{array}{l}\text { Urine incontinence, } \\
\text { decorticated state, } \\
\text { extrapyramidal abnormality, } \\
\text { pathologic reflection }\end{array}$ & $\begin{array}{l}\text { Urine incontinence, } \\
\text { extrapyramidal } \\
\text { abnormality, } \\
\text { pathologic reflection }\end{array}$ & $\begin{array}{l}\text { Extrapyramidal } \\
\text { abnormality, } \\
\text { pathologic } \\
\text { reflection }\end{array}$ & None \\
\hline
\end{tabular}

Abbreviations: d, days; DEACOI, delayed encephalopathy after carbon monoxide intoxication; h, hours; hUCB-MNC, human umbilical cord blood mononuclear cells; y, years.

\section{Discussion}

Stem cell transplantation has been suggested to be a challenging therapeutic method for treating the neurological disorders, blood disorders, diabetes, and other diseases. Animal studies and some clinical trials have provided evidence of therapeutic effects of stem cells for neurodegenerative diseases. Because human embryonic stem cells and fetal brain-derived neural progenitor cells raise ethical concerns and are of limited source, other stem cells such as bone marrow stem cells and umbilical cord blood stem cells have been used in trials 
Table 2 The therapeutic efficacy of the hUCB-MNC transplantation in 12 patients with DEACOI

\begin{tabular}{lllll}
\hline Cases & $\begin{array}{l}\text { Complete } \\
\text { recovery }\end{array}$ & $\begin{array}{l}\text { Partial } \\
\text { recovery }\end{array}$ & Nonresponse & $\begin{array}{l}\text { Effective } \\
\text { rate }\end{array}$ \\
\hline 12 & 7 & 5 & 0 & $100 \%$ \\
\hline
\end{tabular}

Abbreviations: DEACOI, delayed encephalopathy after carbon monoxide intoxication; hUCB-MNC, human umbilical cord blood mononuclear cells.

attempting to treat neurological disorders. ${ }^{21}$ Several progenitor populations were isolated from the cord blood of the newborns and were shown to be able to differentiate to neurons in in vitro and in vivo studies. ${ }^{22,23}$ Recently, bone marrow mensenchymal stem cells have been shown to be effective in treating the 6-hydroxydopamine-lesioned Parkinson's rats. ${ }^{24}$ The systemic and local injection approaches were attempted in order to study the efficacy of the transplanted stem cells in animal models with neurological diseases. Intravenous administration was shown to be effective in preventing and treating stroke in the rat model after a middle cerebral artery occlusion, and it was also shown to increase the recovery of behavioral and neurological functions and rescue the neurons in the ischemic regions..$^{25}$ Other studies showed that hUCB cells improved the special learning and memory ability of transgenic mice with Alzheimer's disease. ${ }^{17,26}$ In this study, we have investigated the safety and feasibility of the transplantation therapy of allogeneic hUCB-MNCs for patients with DEACOI. We injected hUCB-MNCs into patients by lumbar puncture transplantation and found

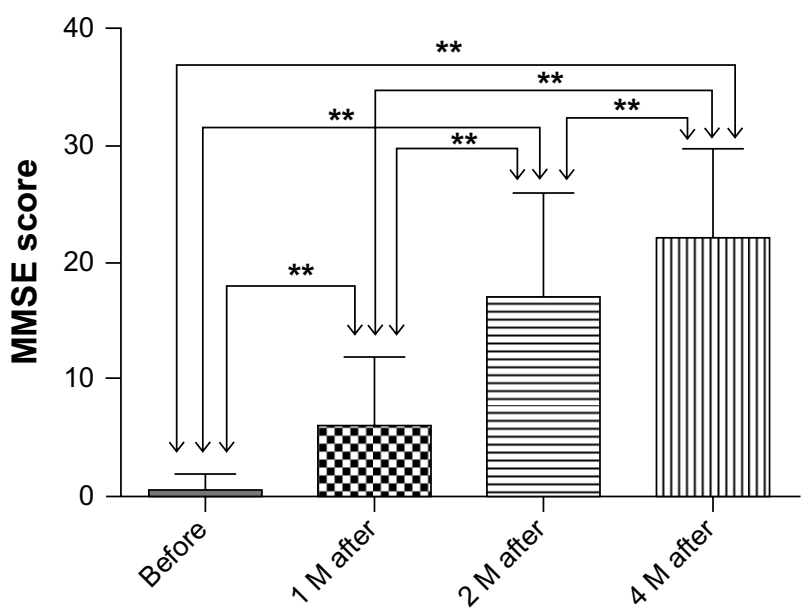

Figure I Comparison of the mini-mental state exam (MMSE) scores of patients with DEACOI before and I, 2, and 4 months after hUCB-MNC transplantation.

Notes: **Indicates that the MMSE scores were significantly increased at I, 2, and 4 months after hUCB-MNC transplantation compared to the MMSE score before transplantation. The bars represent the mean MMSE scores and standard deviation of MMSE scores in each group $(F=33.098, P<0.01)$.

Abbreviations: DEACOI, delayed encephalopathy after carbon monoxide intoxication; hUCB-MNC, human umbilical cord blood mononuclear cells: M, months. that a single transplantation of hUCB-MNCs significantly improved the recovery of the cognitive, memory behaviors, and improved brain $\mathrm{CT}$ scans of the patients in 1, 2, or 4 months of transplantation, suggesting that lumbar puncture transplantation is an effective approach to improve conditions in patients with DEACOI. We have treated 12 patients with DEACOI through lumbar puncture transplantation of the hUCB-MNCs and achieved beneficial efficacy; however, the therapeutic efficiency varies from patient to patient. We noticed that some patients' mental dysfunctions recovered in the first week, whereas other patients' symptoms recovered later than a month after transplantation. Because the total number of cells isolated from the fetal cord blood is different among the individual donors, the number of the transplanted cells is different from patient to patient at the range of $1-2 \times 10^{8} \mathrm{hUCB}-\mathrm{MNCs}$. It seems that after pseudorecovery of patients with $\mathrm{CO}$ intoxication, the earlier the patient underwent hUCB-MNC transplantation therapy, the better the therapeutic role of transplantation was, even though we did not perform statistical analysis because of the limited cases enrolled in this study. In order to determine the optimal efficacy of transplantation, we need to recruit more patients and follow their progress after transplantation therapy for a longer period of time - one or two years. At the same time, a number of DEACOI patients without hUCB-MNC transplantation, as a control group, should be followed to compare the therapeutic effects between the patients who have received transplants and those who have not undergone the treatment. We also need to consider the patient conditions individually, and set up the stem cell treatment plan by a panel of clinicians, research scientists, and administrators to achieve the best therapeutic effects. In this study, we did not observe any signs of immune rejection in any of the patients, even though no immunosuppressive agents were given before or after hUCB-MNC transplantation therapy. This is probably due to the immature antigeneity of the allogeneic hUCB-MNC, which could not induce the immune response in recipients. However, some blood immune cells and antibodies collected from patients post-transplantation remain to be examined in order to provide additional supporting evidence that hUCB$\mathrm{MNC}$ transplantation does not induce an immune rejection response.

The therapeutic mechanism of stem cell transplantation is not completely known. Rather than cell replacement, other possible mechanisms of cell transplantation were proposed to play the important role in stem cell therapy, such as the secreted growth factors that could increase the cell survival and immunomodulation. Some studies indicated that the 

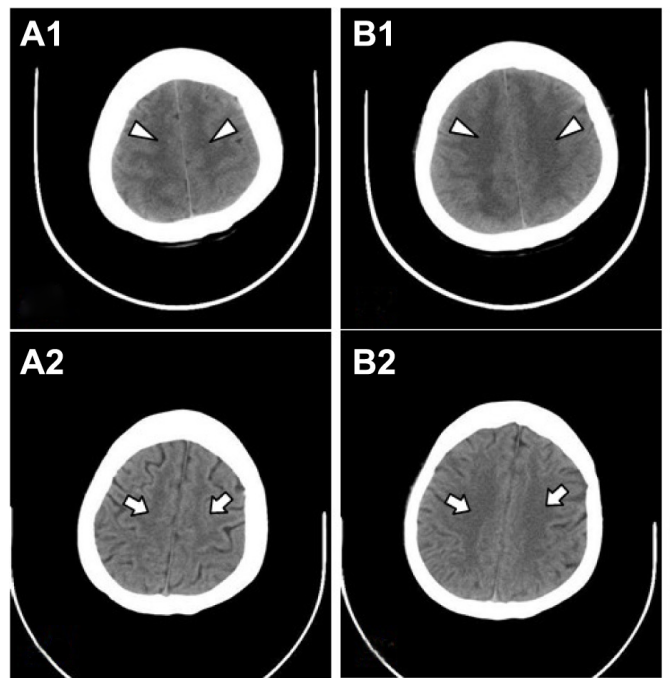
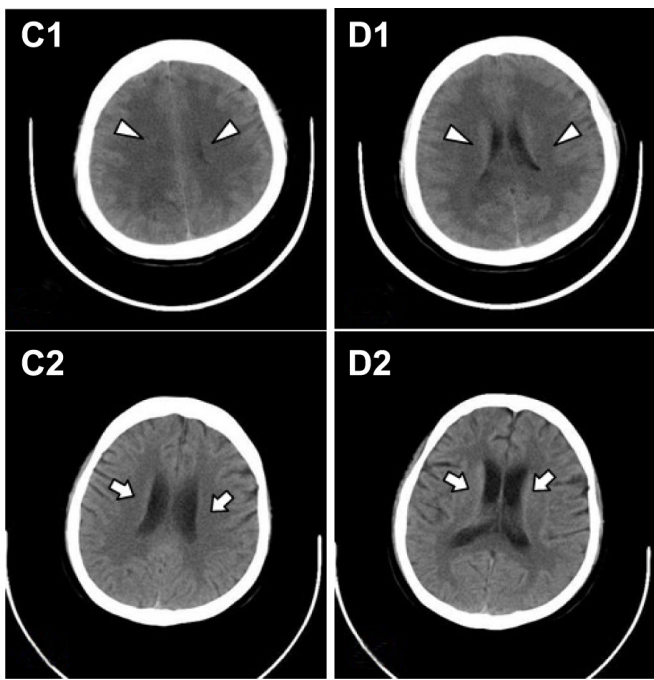

Figure 2 Comparison of the brain computed tomography scans before and 4 months after hUCB-MNC transplantation.

Notes: (AI-DI) indicate that before transplantation, abnormally low signal intensities and diffused images (arrow heads) were seen in the white matter of the frontal, parietal, and occipital lobes, lenticular nucleus, and posterior limb of internal capsule in a patient with DEACOI. (A2-D2) indicate that 4 months after transplantation of the hUCB-MNCs, the abnormal lesions of the affected brain areas had disappeared (arrows).

Abbreviations: DEACOI, delayed encephalopathy after carbon monoxide intoxication; hUCB-MNC, human umbilical cord blood mononuclear cells.

stem cells directly affected the cell survival and microglial survival. ${ }^{27,28}$ Other studies suggested that immunomodulation mechanisms may play the main role in improving neuroprotection of stem cells in treating stroke and neurodegenerative diseases. ${ }^{26,29}$

Since hUCB-MNCs mainly differentiate to mesodermal and endodermal cells, and have limited differentiation into neural cells, other stem cells are being studied for the treatment of the neurological diseases. ${ }^{30,31}$ The most challenging objective in stem cell clinical transplantation is to induce the production of pluripotent stem cells derived from the patient's own somatic cells, such as the fibroblast cells and blood cells, where they are reprogrammed by stem cell factors such as octamer-binding transcription factor 4 (OCT4), sex determining region $\mathrm{Y}$ box 2 (SOX2), Kruppel-like factor 4 (KLF4), and c-Myc. ${ }^{32,33}$ Recent studies have generated human induced pluripotent stem cells from patients with neurological diseases. ${ }^{7,34,35}$ The patient-derived induced pluripotent stem cells have been efficiently differentiated to the dopamine neurons, motor neurons, and interneurons. Transplantation studies have shown the induced pluripotent stem cells-derived neurons survived and migrated to the host brain tissues and improved the locomotive and behavioral activities in animal models with neurodegenerative diseases, and thus provided evidence for the future perspective of stem cell therapy in neurological diseases.

\section{Disclosure}

The authors report no conflicts of interest in this work.

\section{References}

1. O’Donnell P, Buxton PJ, Pitkin A, Jarvis LJ. The magnetic resonance imaging appearances of the brain in acute carbon monoxide poisoning. Clin Radiol. 2000;55(4):273-280.

2. Kawanami T, Kato T, Kurita K, Sasaki H. The pallidoreticular pattern of brain damage on MRI in a patient with carbon monoxide poisoning. J Neurol Neurosurg Psychiatr. 1998;64(2):282.

3. Kamada K, Houkin K, Aoki T, et al. Cerebral metabolic changes in delayed carbon monoxide sequelae studied by proton MR spectroscopy. Neuroradiology. 1994;36(2):104-106.

4. Martinez HR, Gonzalez-Garza MT, Moreno-Cuevas JE, Caro E, Gutierrez-Jimenez E, Segura JJ. Stem-cell transplantation into the frontal motor cortex in amyotrophic lateral sclerosis patients. Cytotherapy. 2009;11(1):26-34.

5. Borlongan CV. Recent preclinical evidence advancing cell therapy for Alzheimer's disease. Exp Neurol. 2012;237(1):142-146.

6. Yasuhara T, Matsukawa N, Hara K, et al. Transplantation of human neural stem cells exerts neuroprotection in a rat model of Parkinson's disease. J Neurosci. 2006;26(48):12497-12511.

7. Ebert AD, Beres AJ, Barber AE, Svendsen CN. Human neural progenitor cells over-expressing IGF-1 protect dopamine neurons and restore function in a rat model of Parkinson's disease. Exp Neurol. 2008;209(1): 213-223.

8. Kim HJ, McMillan E, Han F, Svendsen CN. Regionally specified human neural progenitor cells derived from the mesencephalon and forebrain undergo increased neurogenesis following overexpression of ASCL1. Stem Cells. 2009;27(2):390-398.

9. Schwinger W, Urban C, Lackner H, et al. Unrelated 5/6-locus matched umbilical cord blood transplantation in a 23-month-old child with hemophagocytic lymphohistiocytosis. Bone Marrow Transplant. 1998;22(4):393-396.

10. Pimentel-Coelho PM, Rosado-de-Castro PH, da Fonseca LM, Mendez-Otero R. Umbilical cord blood mononuclear cell transplantation for neonatal hypoxic-ischemic encephalopathy. Pediatr Res. 2012;71(4 Pt 2):464-473.

11. Ende N, Chen R. Parkinson's disease mice and human umbilical cord blood. J Med. 2002;33(1-4):173-180.

12. Mathieu P, Roca V, Gamba C, Del Pozo A, Pitossi F. Neuroprotective effects of human umbilical cord mesenchymal stromal cells in an immunocompetent animal model of Parkinson's disease. J Neuroimmunol. 2012;246(1-2):43-50. 
13. Ende N, Chen R, Ende-Harris D. Human umbilical cord blood cells ameliorate Alzheimer's disease in transgenic mice. J Med. 2001;32(3-4): 241-247.

14. Garbuzova-Davis S, Willing AE, Zigova T, et al. Intravenous administration of human umbilical cord blood cells in a mouse model of amyotrophic lateral sclerosis: distribution, migration, and differentiation. J Hematother Stem Cell Res. 2003;12(3):255-270.

15. Sanberg PR, Eve DJ, Willing AE, et al. The treatment of neurodegenerative disorders using umbilical cord blood and menstrual blood-derived stem cells. Cell Transplant. 2011;20(1):85-94.

16. Kim JY, Kim DH, Kim JH, et al. Soluble intracellular adhesion molecule-1 secreted by human umbilical cord blood-derived mesenchymal stem cell reduces amyloid- $\beta$ plaques. Cell Death Differ. 2012;19(4):680-691.

17. Lee HJ, Lee JK, Lee H, et al. The therapeutic potential of human umbilical cord blood-derived mesenchymal stem cells in Alzheimer's disease. Neurosci Lett. 2010;481(1):30-35.

18. Riegelsberger UM, Deten A, Pösel C, et al. Intravenous human umbilical cord blood transplantation for stroke: impact on infarct volume and caspase-3-dependent cell death in spontaneously hypertensive rats. Exp Neurol. 2011;227(1):218-223.

19. Hopkins RO, Woon FL. Neuroimaging, cognitive, and neurobehavioral outcomes following carbon monoxide poisoning. Behav Cogn Neurosci Rev. 2006;5(3):141-155.

20. Gauthier S, Feldman H, Hecker J, Vellas B, Emir B, Subbiah P; Donepezil MSAD Study Investigators' Group. Functional, cognitive and behavioral effects of donepezil in patients with moderate Alzheimer's disease. Curr Med Res Opin. 2002;18(6):347-354.

21. Newman MB, Davis CD, Borlongan CV, Emerich D, Sanberg PR. Transplantation of human umbilical cord blood cells in the repair of CNS diseases. Expert Opin Biol Ther. 2004;4(2):121-130.

22. Li X, Li H, Bi J, Chen Y, Jain S, Zhao Y. Human cord blood-derived multipotent stem cells (CB-SCs) treated with all-trans-retinoic acid (ATRA) give rise to dopamine neurons. Biochem Biophys Res Commun. 2012;419(1):110-116.

23. Slovinska L, Novotna I, Kubes M, et al. Umbilical cord blood cells CD133+/CD133- cultivation in neural proliferation media differentiates towards neural cell lineages. Arch Med Res. 2011;42(7):555-562.
24. Khoo ML, Tao H, Meedeniya AC, Mackay-Sim A, Ma DD Transplantation of neuronal-primed human bone marrow mesenchymal stem cells in hemiparkinsonian rodents. PLoS One. 2011;6(5):e19025.

25. Newcomb JD, Ajmo CT, Sanberg CD, Sanberg PR, Pennypacker KR, Willing AE. Timing of cord blood treatment after experimental stroke determines therapeutic efficacy. Cell Transplant. 2006;15(3): 213-223.

26. Lee HJ, Lee JK, Lee H, et al. Human umbilical cord blood-derived mesenchymal stem cells improve neuropathology and cognitive impairment in an Alzheimer's disease mouse model through modulation of neuroinflammation. Neurobiol Aging. 2012;33(3):588-602.

27. Jiang L, Womble T, Saporta S, et al. Human umbilical cord blood cells decrease microglial survival in vitro. Stem Cells Dev. 2010;19(2): 221-228.

28. Yuan T, Liao W, Feng NH, et al. Human induced pluripotent stem cellderived neural stem cells survive, migrate, differentiate, and improve neurological function in a rat model of middle cerebral artery occlusion. Stem Cell Res Ther. 2013;4(3):73.

29. Park DH, Borlongan CV, Willing AE, et al. Human umbilical cord blood cell grafts for brain ischemia. Cell Transplant. 2009;18(9):985-998.

30. Barker RA. Stem cells and neurodegenerative diseases: where is it all going? Regen Med. 2012;7(6 Suppl):26-31.

31. Martínez-Morales PL, Revilla A, Ocaña I, et al. Progress in Stem Cell Therapy for Major Human Neurological Disorders. Stem Cell Rev. Epub 2013 May 17.

32. Yu J, Vodyanik MA, Smuga-Otto K, et al. Induced pluripotent stem cell lines derived from human somatic cells. Science. 2007;318(5858): 1917-1920.

33. Takahashi K, Tanabe K, Ohnuki M, et al. Induction of pluripotent stem cells from adult human fibroblasts by defined factors. Cell. 2007;131(5): 861-872.

34. Soldner F, Hockemeyer D, Beard C, et al. Parkinson's disease patientderived induced pluripotent stem cells free of viral reprogramming factors. Cell. 2009;136(5):964-977.

35. Jung YW, Hysolli E, Kim KY, Tanaka Y, Park IH. Human induced pluripotent stem cells and neurodegenerative disease: prospects for novel therapies. Curr Opin Neurol. 2012;25(2):125-130.
Journal of Neurorestoratology

\section{Publish your work in this journal}

The Journal of Neurorestoratology is an international, peer-reviewed, open access online journal publishing original research and review articles on the subject of Neurorestoratology. To provide complete coverage of this revolutionary field the Journal of Neurorestoratology will report on relevant experimental research, technological advances, and

\section{Dovepress}

clinical achievements. The manuscript management system is completely online and includes a very quick and fair peer-review system, which is all easy to use. Visit http://www.dovepress.com/testimonials.php to read real quotes from published authors. 